\title{
Disond
}

Revista Educación

ISSN: 0379-7082

ISSN: 2215-2644

revedu@gmail.com

Universidad de Costa Rica

Costa Rica

\section{Critical Thinking for Civic Life in Elementary Education: Combining Storytelling and Thinking Tools}

\author{
Mena Araya, Aarón Elí \\ Revista Educación, vol. 44, núm. 2, 2020 \\ Universidad de Costa Rica, Costa Rica \\ Disponible en: http://www.redalyc.org/articulo.oa?id=44062184007 \\ DOI: https://doi.org/10.15517/revedu.v44i2.39699
}

Critical Thinking for Civic Life in Elementary Education: Combining Storytelling and Thinking Tools

Esta obra está bajo una Licencia Creative Commons Atribución-NoComercial-SinDerivar 3.0 Internacional. 


\title{
Critical Thinking for Civic Life in Elementary Education: Combining Storytelling and Thinking Tools
}

\author{
Pensamiento crítico para la vida ciudadana en educación primaria: combinando narrativa y herramientas de \\ pensamiento
}

Aarón Eli Mena Araya

Universidad de Costa Rica, Costa Rica

aaron.menaaraya@ucr.ac.cr

iD http://orcid.org/0000-0002-2577-2221

\author{
DOI: https://doi.org/10.15517/revedu.v44i2.39699 \\ Redalyc: http://www.redalyc.org/articulo.oa?id=44062184007
}

Recepción: 06 Diciembre 2019

Aprobación: 17 Abril 2020

\begin{abstract}
:
Teaching critical thinking involves developing specific thinking skills and nurturing attitudes that are necessary for adequate use these of these skills in everyday life situations. The required skills and attitudes required by students to approach problems that affect their own communities can be taught by designing and executing learning activities where students use storytelling, for example. This study focuses on designing and executing two learning units for critical thinking instruction on citizenship education in a Costa Rican elementary school. These units combine the use of story-based materials, such as animated films, digital comic strips, and thinking tools. Additionally, an assessment method is proposed which is based on analysis of the comic strips created by the students. This method analyzes the logical structure behind comic strips to help determine to what extent critical thinking skills are applied with a focus on specific thinking skills such as inference and analysis. The results of the assessment suggest that when students participate in learning units, such as the use of story-based media and thinking tools, they can express a higher level of critical thinking skill application in the stories they create.
\end{abstract}

KEYwords: Critical Thinking, Storytelling, Comic Strips, Citizenship Education.

\section{RESUMEN:}

La enseñanza del pensamiento crítico involucra el desarrollo de habilidades de pensamiento específicas, y de las actitudes necesarias para aplicar oportunamente dichas habilidades a situaciones de la vida cotidiana. Mediante el diseño e implementación de actividades de aprendizaje en las cuales los estudiantes utilizan la narrativa para abordar los problemas que afectan sus propias comunidades, es posible equiparlos con las habilidades y actitudes que requieren. Este estudio describe el proceso de diseño e implementación de dos unidades para la instrucción del pensamiento crítico para la vida ciudadana en una escuela primaria de Costa Rica. Estas unidades combinan el uso de recursos narrativos, como cortos animados e historietas, y herramientas de visualización de pensamiento. Adicionalmente se propone un método de evaluación basado en el análisis de historietas creadas por los estudiantes. Este método analiza la estructura lógica de las historietas, y busca determinar el nivel de aplicación de habilidades de pensamiento crítico expresado en ellas, enfocándose en habilidades específicas como la inferencia y el análisis. Los resultados de la evaluación sugieren que a través de la participación en unidades de aprendizaje que integran el uso de medios narrativos y herramientas de pensamiento, los estudiantes pueden expresar un mayor nivel de aplicación de habilidades de pensamiento crítico en las historias que ellos mismos crean.

Palabras ClaVe: Pensamiento crítico, Narrativa, Historietas, Educación Cívica.

\section{INTRODUCTION}

Critical thinking is a fundamental skill for citizens of the $21^{\text {st }}$ century, since it allows them to find solutions for social issues affecting both local and global communities. Elementary school students struggle to comprehend and become involved in these issues. Many children do not seem to be able to draw their own conclusions on these issues, or acquire the habit of consolidating and expressing their own ideas through reflection and dialogue (Yamashita, Yuizono, Umezawa \& Kasuya, 2017). 
These difficulties are closely related to the structural characteristics of elementary school education where elementary school students normally engage in learning within the confines of the classroom, protected from the uncertainties and perils of the outside world. Under such circumstances, social issues become distant realities. As a result, children struggle to view themselves as citizens who are able to participate in identifying and solving social issues in their communities. On the road to adulthood, students embrace a superficial understanding of the concepts and mechanisms related to democratic life, which hinders their ability to become active citizens (Arce, 2019).

In 2006 Costa Rica began a comprehensive review of their school curriculum, focusing on adding critical thinking skills. While critical thinking was introduced in teaching Spanish in Elementary Education with the objective of enhancing learner reading and argumentation skills. Scientific Thinking Development was also included in the Science curriculum as the foundation for inquiry and experimentation (MEP, 2009). In addition, creative thinking was incorporated into the Arts and Crafts curriculum as a tool for learners to explore and express their own individuality. Furthermore, by equipping public schools with digital devices, MEP sought to provide students with opportunities to gain control of their own learning and apply their critical, creative and problem-solving skills.

MEP approaches critical thinking as the ability to analyze facts, create and organize ideas, draw conclusions, defend opinions, make comparisons, evaluate arguments and solve problems (Chance, 1986). Critical thinking is appropriately viewed as a cluster of skills that can be developed in a cross-cutting manner through different subjects. Project-based learning is also proposed as a suitable methodology for fostering critical thinking in the classroom (MEP, 2009). This methodology addresses learning from a constructivist perspective and allows learners to develop their own talents and abilities so they can organize information and use concepts and procedures to solve problems. During project-based learning activities, teachers are required to encourage active student participation by selecting objects they can learn from in their everyday lives. Thus, project-based learning allows children to focus on their own communities while engaging in inquiry and creativity. How have these policies impacted teaching practices in Costa Rican elementary schools? Where is it possible to observe tangible efforts to facilitate the development of critical thinking skills? To what extent are narrative and other resources incorporated into these learning experiences?

MEP published compilations of learning activities specifically aimed at fostering critical thinking skills, some which include the design and utilization of narrative resources. During these activities, learners may write short stories and create drawings to connect the concept of tolerance with their own lives. They may also use animated movies to reflect on challenges faced by people with disabilities (MEP, 2006). Thinking tools help analyze the role characters play in a story and may resort to political cartoons to discuss history and social events. The projects are presented as useful examples of how critical and creative thinking skills can be taught across the curricula of multiple subjects.

In order to promote abilities involving collaboration, media literacy, critical thinking, problem-solving and decision making within a framework of ATC21S Skills (Griffin, McGaw \& Care, 2012), the ATC21S Project was conducted jointly between MEP and the Omar Dengo Foundation (Bujanda \& Campos, 2014) from 2012 to 2014. Costa Rica was selected to represent the Latin America Region for the ATC21S Project which involved the participation of middle school students from Australia, Singapore, the United States of America, Netherlands and Finland. In Costa Rica, 24 teachers and 776 students participated in Artic Trek and Webspiration, two learning units previously designed to support teaching ATC21S skills. Artic Trek focuses on the utilization of multiple sources of scientific information and prompts students to participate in scientific inquiry while collaborating through social media. Webspiration, promotes the use of audiovisual materials to analyzed poetry. Execution of this unit required the production of 18 short films in which renowned Costa Rican artists and athletes share their thoughts about poetry and read their favorite poems.

The ATC21S Project also involved the design and publishing of a set of digital tools to provide support for ATC21S skills instruction. These materials included short animated films and apps/applications that 
students can use to create comic strips, many of which are available in the MEP digital library. The $A T C 21 S$ Project has been Costa Rica's most significant effort in incorporate elements of narrative to teaching critical thinking.

Project Ethics, Esthetics and Citizenship, also serves as the basis for a new method of Citizenship Education, while emphasizing strengthening interpersonal relationships and social cohesion. A new Social Studies and Citizenship Education curriculum was implemented in 2008. This suggests that learning activities in Citizenship Education should be organized based on three dimensions (Arce y Chévez, 2016). The first dimension is the cognitive dimension, which involves understanding the characteristics of democratic institutions and procedures for solving problems in local, national and global contexts. The second dimension involves the development of skills that are useful for citizen life and social participation. The last dimension emphasizes the formative aspects of Citizenship Education, such as values and attitudes required by citizens to make sound decisions within the democratic system.

It may be argued that the impact of the aforementioned policies and projects have been delimited and localized, based on assessments of the new Citizenship Education curriculum. However, implementation of the curricula has been hindered from lack of comprehensive planning, difficulties in advancing pending tasks resulting from changes in project management, teacher resistance in overcoming traditional instruction practices and limited availability of educational materials needed by schools and communities (Sans, Jenkins \& Elizondo, 2009). Likewise, Citizenship Education has traditionally been regarded as a theoretical subject, detached from current social issues. Consequently, Citizenship Education curricula have been generally limited to the transmission of vaguely connected political concepts that hold little meaning for the students (Arce, 2019).

Most teachers still face the challenge of selecting and designing activities that may contribute to the development of critical thinking skills, while maintaining the student enthusiasm. Furthermore, the scarcity of educational media focusing specifically on the issues of Costa Rican communities makes it harder for teachers to approach teaching this aspect of Citizenship Education.

The purpose of this study is to develop a set of story-based learning units aimed at providing students with the procedural knowledge and attitudes they need to be able to analyze problems faced by their communities and propose their own solutions. Additionally, methods are proposed for assessing the level of learning of the students. Theory and methods currently used by Japanese elementary schools are used as a reference for critical thinking instruction.

\section{Theoretical Framework}

This section describes the process of analysis on which the design of the learning units and educational media are based. It also lays out the purpose of critical thinking instruction in civic life and specific procedures that support the development of critical thinking.

\subsection{The Purpose of Teaching Critical Thinking in Civic Life}

Critical thinking and civic literacy are deeply intertwined. Civic literacy can be understood as functional literacy which involves knowledge about politics, economy, health, law, sciences and other domains as well as applied critical thinking skills (Kusumi \& Michita, 2016). Moreover, civic literacy emphasizes the acquisition of reading and communication skills supported by knowledge, skills, and attitudes commonly related to critical thinking. In this study, critical thinking is approached as reasonable and reflective forms of thinking that allow citizens to decide what to believe and what actions to take (Ennis, 1985). Accordingly, the 
discussed learning units aim to reinforce effective application of logical thinking to problem-solving and decision-making within the context of community life.

While acknowledging the close relationship between critical thinking and Citizenship Education, Kusumi (2013) divides the critical thinking process into four interrelated steps: Clarification of the Information, Building Foundations for Inference, Making Inferences and decisions, Solving Problems. By following these steps, children are expected to effectively use different types of information, investigate the cause of a problem and propose adequate solution strategies based on inference.

This study has two purposes in teaching critical thinking for civic life. First, it seeks to awaken student interest in the issues affecting their school and local communities. In doing so, children gain awareness regarding how they view themselves as citizens in their own communities and will, ultimately, become interested in social issues. Second, this study has the objective of teaching children thought organizing tools which are useful for analyzing and resolving social issues. It is a way of introducing the procedural knowledge required by them for solving everyday problems they may encounter. Through this two-pronged approach, it is expected that critical thinking instruction will contribute significantly to their becoming better and more informed citizens.

\subsection{The Objective of Critical Thinking}

The objective of critical thinking is to refer to the issues the learners are required to think about more critically. In order to properly select the issues, it is necessary to identify specific learning content dealing with the objectives involved in teaching critical thinking. Thus, learning units should focus specifically on problems involving school and community life addressed strictly from a child's perspective.

Although learning units are conceived as projects to be executed within the classroom, when choosing specific problems to be addressed, the issues usually encountered during service-learning are suitable outlines. These involve urban development, road traffic security, disaster prevention, healthcare, criminality, pollution and other environmental issues (Karaki, 2008). When dealing with such issues, students are required to use their knowledge and skills in different subject matters. Learning units are not encased within any particular subject. They can contribute to the achievement of learning objectives in subjects such as Social Studies and Citizenship Education, Science and Spanish.

The learning unit, Contemporary Costa Rican Society: Challenges and Opportunities in the Global Context, part of the Social Studies and Citizenship Education curriculum for 6th graders allows students the opportunity to duly address problems that affect school and communities. The goal of this unit is to provide students with the abilities they need to cope with problems of contemporary society (MEP, 2013). This unit includes conceptual contents such as student self-awareness as citizens who can be a proactive part of society, procedural contents such as the critical thinking skills needed to effectively approach social issues and attitudes such as the motivation to actively participate in society.

\subsection{Specific Procedures to Supporting Critical Thinking Development}

This study proposes the combined use of thinking tools and story-based educational materials to help foster critical thinking skills for civic life in the context of elementary education. This section explains the link between thinking skills and thinking tools, and the merits of introducing thinking tools and storytelling to the instruction of critical thinking. 


\subsubsection{Thinking Skills and Thinking Tools}

One of the main challenges faced by teachers when dealing with critical thinking instruction is its crosscutting and all-encompassing nature. Critical thinking skills are expected to be readily used in a wide range of contexts. But most of the time, there are no obvious cues to guide students as to when and how they should apply their critical thinking skills. Learners are required not only to understand and apply specific thinking skills, but to be able to recognize situations in which those specific skills should be used (Halpern, 1998). These facts reveal the importance of conceiving and teaching general thinking skills that can be learned for specific settings and then smoothly transferred to other domains.

Critical thinking tools are graphic organizers designed to help learners visualize a though process. Venn diagrams, mind maps and PMI charts are among the most widely known thinking tools. In recent years, the systematic use of multiple thinking tools has been adopted by elementary schools in Japan. Kansai University Elementary School's Muse Learning, and Tsukuba Municipal Kasuga Gakuen Compulsory Education School's Time for Thinking are accurate examples of complementary curricula, centered on the use of thinking tools to promote general thinking skills. Both schools address general thinking skills as a process of acquisition and activation of individual thinking skills as forms of procedural knowledge (Taizan, Kojima \& Kurokami, 2012).

Muse Learning defines multilateral viewing, comparing, classifying, associating, evaluating and structuring as the six main thinking skills taught in the classroom (Tamura \& Kurokami, 2017). Time for thinking includes the same six skills and adds two more: Inferring and Analyzing (Kasuga Gakuen Compulsory Education School, 2017). Even though these thinking skills involve specific cognitive processes that occur in the mind of learners, thinking tools allow students to visualize the results of these processes. When searching for solutions to complex problems of school and community life, learners are usually required to classify, analyze, make inferences, and evaluate proposals. Thinking tools can effectively support all of these tasks.

\subsubsection{Introducing Storytelling to Critical Thinking Skills Instruction}

Paul, Binker and Weil (1990) assert that critical thinking principles should be taught in a manner that is intuitive for children so they are able to truly embrace and apply them to everyday life. Abstract concepts, such as democracy and citizenship can be learned well only when students are able to effectively and spontaneously apply them to the challenges of real life. By integrating pictures, dramatizations, references to everyday life situations and other narrative elements when teaching critical thinking skills, it is possible to provide students with an intuitive understanding of what thinking critically actually entails. Some forms of storybased media, such as animated films and comic strips, can have a particularly positive effect on comprehension and thinking skills, since children find them to be both familiar and exciting (Frey \& Fischer, 2008). Comic strips can also play a particularly effective role in nurturing children's empathy and willingness to express their own ideas and attitudes deeply related to active citizenship (Flynn, 2018).

Moreover, the use of story-based materials can help students express themselves in logical ways. Children can make deep and meaningful connections among the stories they observe, listen and read as well as their own life experiences. Accordingly, critical thinking instruction can be significantly enhanced with stories depicting characters that create sympathy and empathy.

In most learning activities that involve the use of thinking tools, information in presented and organized through explanation and exposition. In order to support specific cognitive processes to help children assimilate community issues, information must be presented in a way that is more appealing and comprehensible to them. The learning units proposed in this study are structured through a combination of thinking tools and story-based media. Students can use animated short films, thinking tool worksheets and 
comic editing software to organize and express their own ideas. Animated films used in the learning units portray children as the protagonists, making it easier for students to relate and identify with their struggles and motivations. Students are also given the opportunity to create their own stories in the form of comic strips, based on the animated films.

\section{Method}

This study uses the framework of instructional design to teach critical thinking skills for citizen life through analysis, design, development, implementation and evaluation, as established by Schlegel (1995). Instructional design involves the development of comprehensive models aimed at enhancing the effectiveness and appeal of learning activities. It also deals with the practical application of these models to create specific learning environments (Suzuki, 2005). While the considerations compiled in the previous two sections describe the findings of the Analysis stage this section focuses on the results of the Design and Development stages. The Execution and Assessmentstages are covered in the results section.

\subsection{Target School}

A D3 (ranging between 200 and 400 students) public elementary school was selected as the target of the learning and assessment activities. Out of the 4039 public elementary schools operating in Costa Rica in 2019, 2853 (70.6\%) are categorized as D3 schools (MEP, 2019). Even though the learning experiences of any school is always influenced by the socioeconomic and geographical conditions of the communities where they are located, D3 schools offer a reliable picture of the typical learning experiences of children in the Costa Rican public education system. This target school, located in Alajuela province, had 312 elementary school level students at the beginning of the 2019 school year.

\subsection{Design and Development of the Learning Units}

In 1998, Japan established the Period for Integrated Study as a new subject for elementary and lower secondary school. This is a weekly lesson in which students can engage in cross-curriculum studies related to all the other subjects, seeking to provide schools with the independence to freely address contents that properly reflect the characteristics of their communities (Murata \& Yamaguchi, 2010). Because of its cross-cutting nature, the Period for Integrated Study is a suitable space for the teaching critical thinking skills. Muse Learning and Time for thinking are both examples of how schools can use their integrated studies timeslots for this purpose.

Elementary schools in Costa Rica do not have an independent subject for systematic instruction of crosscurricula contents. Consequently, such contents must be addressed as subjects taught during regular lessons. Nonetheless, when designing learning activities for cross-subject instruction of critical thinking in Costa Rican schools, Japanese integrated learning experiences can yield valuable insights. In this study, learning units were designed according to the structure defined as a guide for the engagement in inquiry learning activities within the Period of Integrated Learning. This structure includes problem setting, information gathering, organization and analysis, summary and expression as its four main stages (Ministry of Education, Culture, Sports, Science and Technology (Japan), 2011).

In both learning units, stages one and four focus on the use of story-based media, such as short animated films and digital comic strips. In the second and third stages, thinking tool worksheets are extensively use, along with supplementary printed materials. However, it should be noted that throughout every stage of the learning process, thinking tools and story-based materials support and complement each other in different manners. Story-based materials present the problems that need to be solved by using thinking tools. Likewise, thinking tools help children conceive ideas that they will later express as a narrative in a digital comic strip. 
Depending on the actual learning goals and thinking skills in a learning activity, suitable graphic organizers can be selected from a list of over twenty thinking tools (Kurokami, Kojima \& Taizan, 2012). Learning units combine two sets of thinking skills handled by both Muse Learning and Time for Thinking: Classifying and Multilateral Viewing. Although only present in Time for Thinking, Analyzing and Inferring are also included in the learning units. All of these four thinking skills are considered to be abilities children may need when participating in cross-curriculum learning activities (Taizan, Kojima \& Kurokami, 2014). Figure 1 displays thinking skills addressed in the learning units, thinking tools used to nurture those thinking skills and the specific tasks associated with each thinking tool.

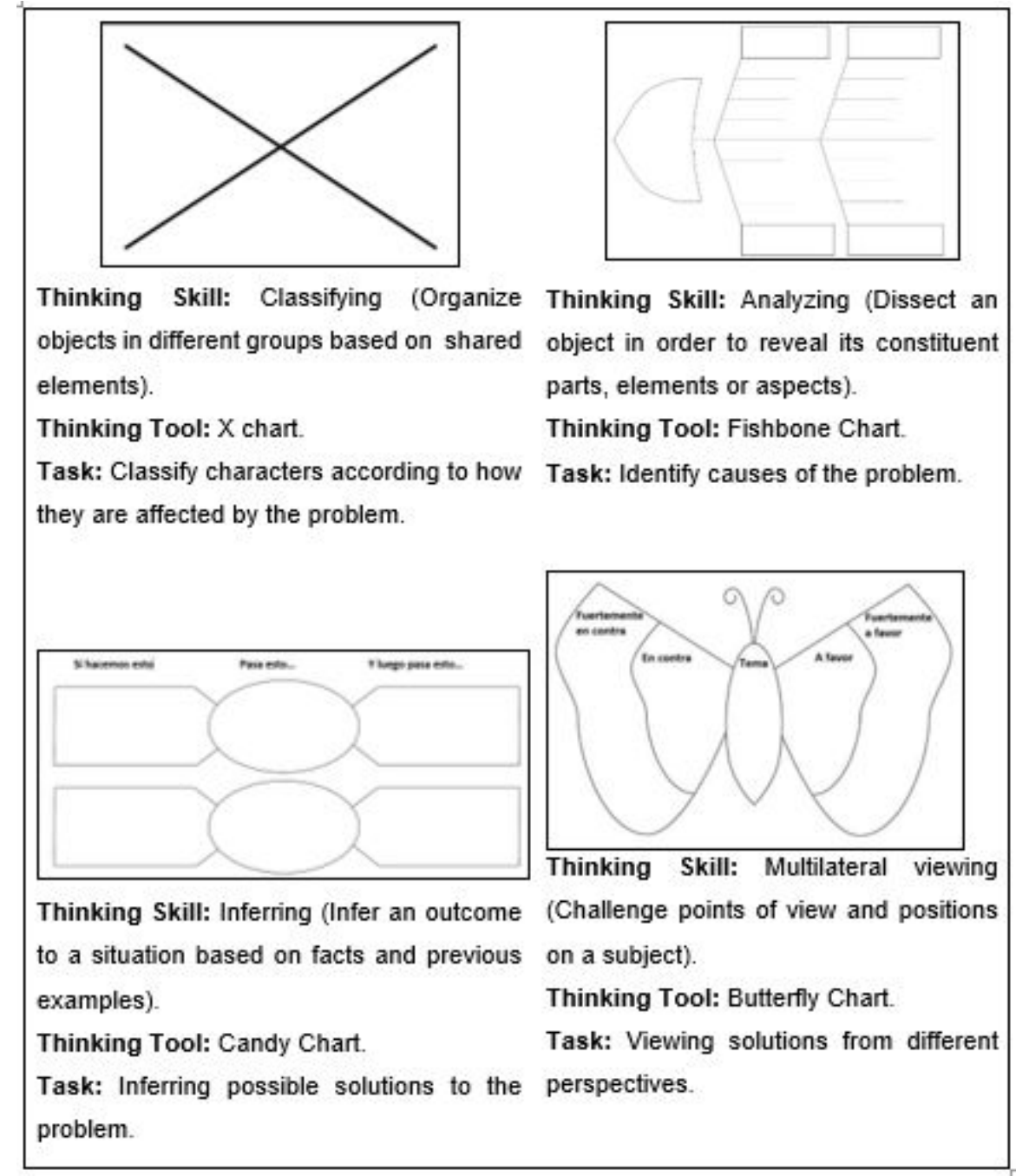

FIGURE 1

Thinking Skills and Thinking Tools Used in Learning Units.

Source: Elaborated by the author based on Kasuga Gakuen Compulsory Education School (2015).

In order to facilitate assessment of how children apply critical thinking skills and acquire more selfawareness as citizens, learning and assessment activities in both units were arranged slightly different. In the first learning unit, students began the activities by viewing an animated film. Immediately afterwards, they use comic plan worksheets and comic editing software to create a digital comic strip that presents a solution to the problem. As a last step, they rethink the solution to the problem, using the four above-mentioned thinking tools. Since this is the first unit in which the students have their first learning experience with thinking tools, emphasis is placed on the purpose of each tool how to use them. 
The second unit begins with an animated film. The students then use three of the four thinking tools (X chart, fishbone chart and candy chart) to analyze the problem and propose a solution. Then, they plan and create a comic strip showing the solution. Once the last remaining thinking tool (Butterfly Chart) is used to express their own opinions about three of the solutions proposed by their peers, the students a vote on the solution they believe to be the most appropriate. Although both units organize learning activities in a different order, both include all of the four stages defined for inquiry learning processes within the Period for Integrated Study.

\subsubsection{Problem Setting}

The problems presented in the learning units were selected through a three-step process. For the first step, 14 teachers in charge of 5th and 6th grade classes in four different schools were asked to name the main problems faced by communities where the schools are located. A list of problems commonly addressed in service-learning was used as reference. Public crime-related insecurity, lack of recreational infrastructure, pollution and road traffic safety problems were among the issues most commonly mentioned by the teachers. The second step involved identifying problems that could be simultaneously approached from a personal dimension (student), community dimension (school, household and civic organizations) and an institutional dimension (local and national government). For the final step problems were selected through a cross-curriculum approach involving 6th grade Science, Spanish, and Social Studies and Citizenship Education for 6th grade. Two problems were selected: Road Safety around Schools and Littering at School 


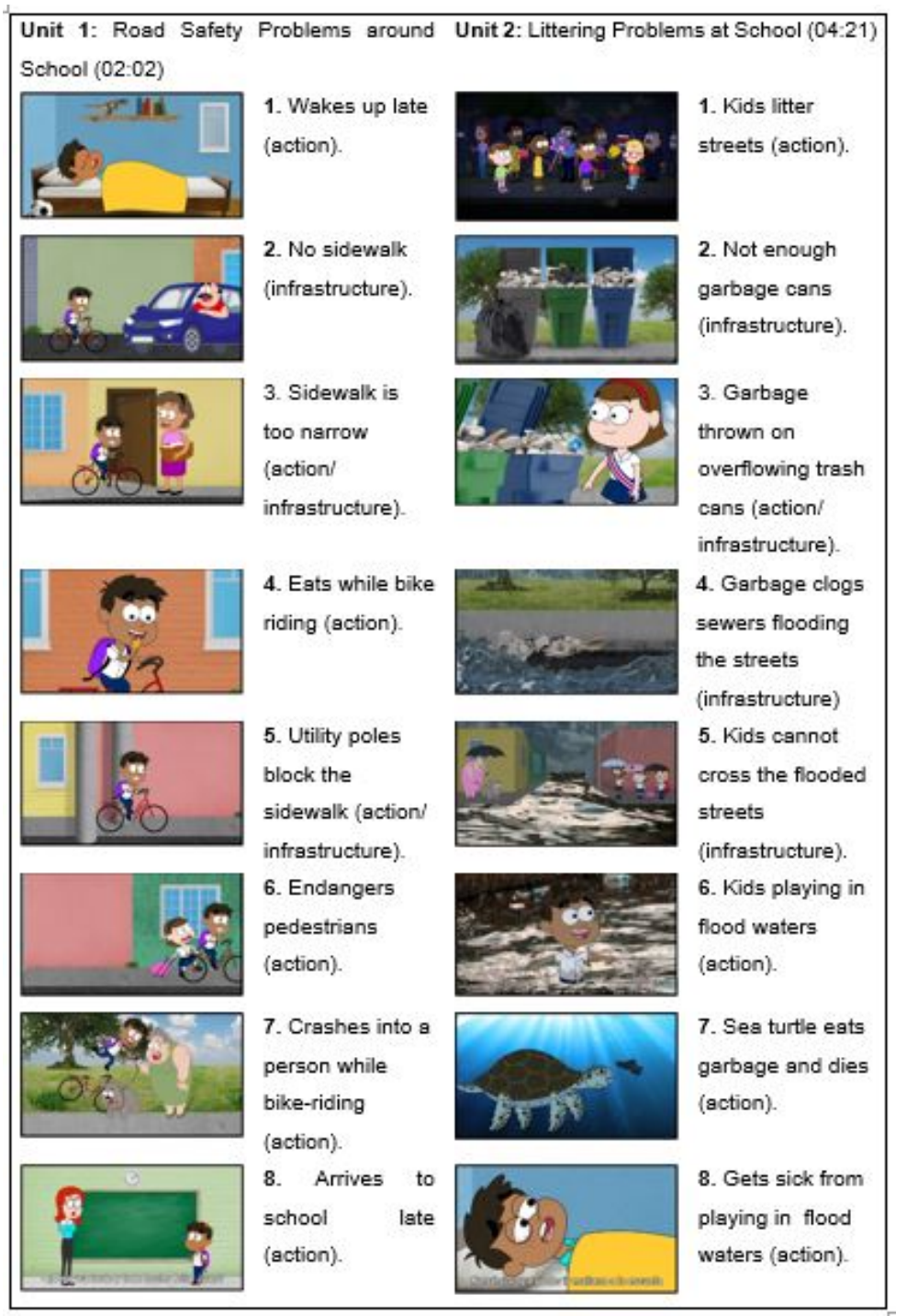

FIGURE 2

Problems Depicted in Animated Short Films

Source: Elaborated by the author

In the Problem Setting stage, students are expected to identify a problem and gain insight about its implications by participating in activities that they can relate to through their own personal experience (Ministry of Education, Culture, Sports, Science and Technology, 2011). In both learning units, the animated short films depict several individual actions and situations linked to a community problem. Thus, animated films accomplish the function of presenting the problem to be analyzed by the students. The animated films that are presented reflect many types of issues that are all under the umbrella of a larger issue that is addressed, such as a problem that one of the characters may face or problems related to community (Figure 2).

After viewing the animated film, students must identify how the characters featured in the film are affected by the problem. The students are then asked to write down their ideas on an X Chart worksheet. Their ideas are then discussed by the entire class. All of these activities from viewing the film to the class discussion, are covered in a single lesson. 


\subsubsection{Information Gathering, Organization and Analysis}

During the information gathering stage, the students compile the information required to complete the task. This information is drawn from the animated short films and supplementary printed materials. The ideas on the $\mathrm{X}$ chart worksheets also provide useful information for understanding the nature and scope of the problem (Figure 3).

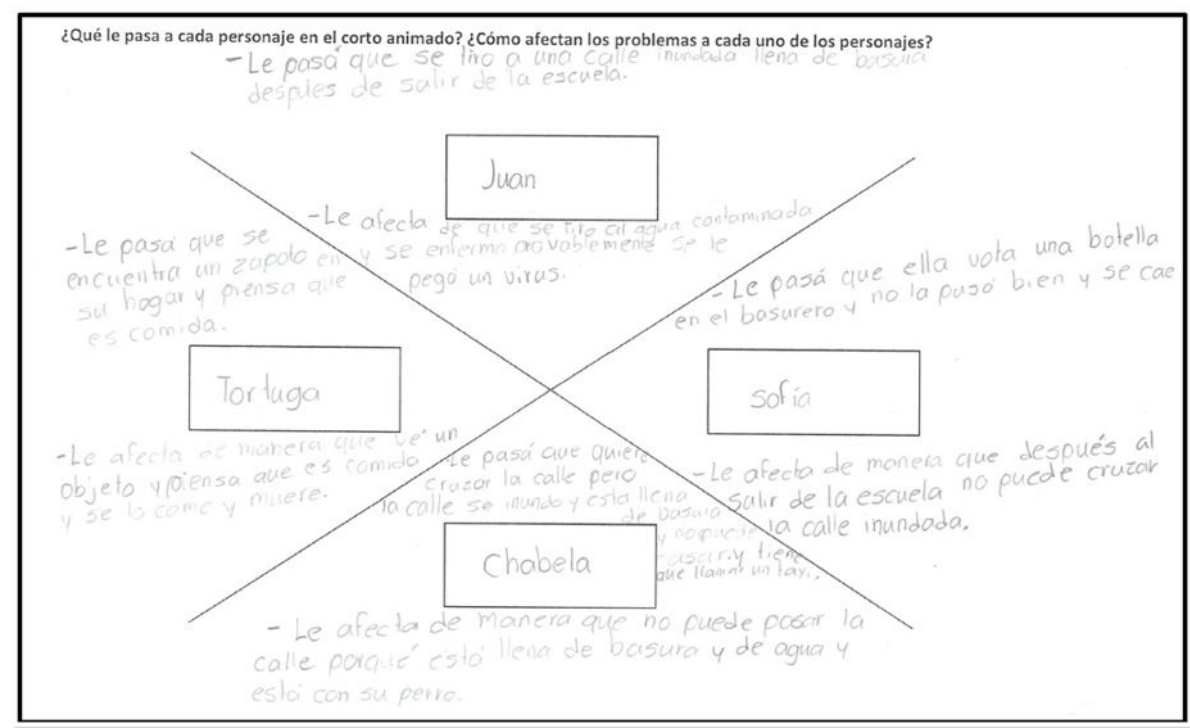

FIGURE 3

X Chart Worksheet Completed by a Student Source: X Chart worksheet filled-out by student

During the organization and analysis stage, students analyze the collected data. They are allowed to watch the animated films again to better reflect and discuss the causes of the problems being addressed. The fishbone chart is used to analyze the causes, thereby providing the students with a more profound understanding about the complexity of social problems, multiple causes and the possible solutions. In the first learning unit, upon analyzing the cause of the problem, the students are given a map of the school and its vicinity. The map is numbered in areas where problems similar to those portrayed in the films actually occurred in real-life. Worksheets with photographs of the numbered areas on the map are also distributed. Through concurrent use of these supplementary materials, students better engage in analyzing and understanding familiar situations (Figure 4). Once students understand the different causes of the problem, they can propose their own solutions. Students proceed to list possible solutions on a candy chart worksheet that is then distributed. 


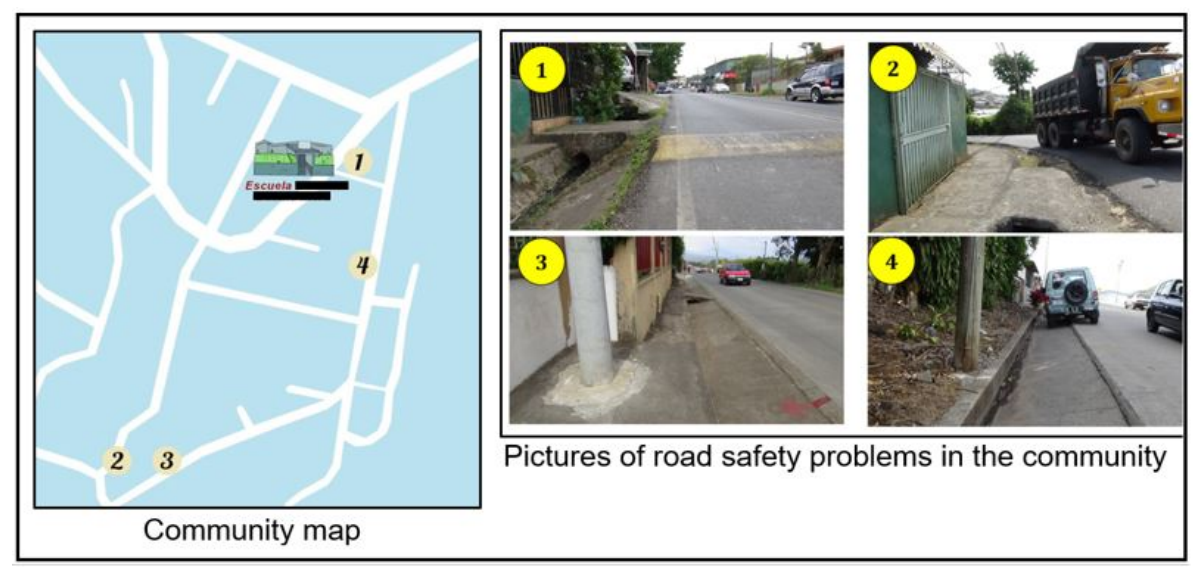

FIGURE 4

Unit 1 Supplementary Materials

Source: Elaborated by the author

As noted above in the two stages above, critical thinking worksheets function as a scaffold to help children decode crucial bits of information that are hidden in the plots of the animated films. Therefore, students are able to extract information they need to solve the problem while filtering this information through their own personal perspective. The fishbone chart and candy chart activities are covered in two lessons. It is important to highlight that, although students are able to discuss their ideas once they are written on the worksheet, they are encouraged to express their own solutions to the problem individually.

\subsubsection{Summary and Expression}

During the summary and expression stage, students are expected to summarize their own findings and ideas, make judgments on how they should act based on those ideas and express them in clear and creative ways. Students then create their own digital comic strip depicting a minimum of one solution they proposed in the candy chart worksheet. By asking the children to create their own comic strips, problem solving, design and revision processes are facilitated that may lead to the development of attitudes and skills related to a variety of literacies (Comer, 2015).

The students use a comic strip planning worksheet which describes the basic characteristics of comic strips and includes a table where they can organize the characters and actions to be depicted in each panel of the comic strip. The worksheet also includes pictures of the main characters of the story, so the students can verify their names and characteristics. With the aim of helping children arranging their stories in a logical sequence, a four-panel structure is suggested for the comic strips: the problem and its causes (one panel), the solution to the problem (two panels), and the new situation in which the problem has been solved (one panel).

The digital comic strips are created in the school computer laboratory using Voicing board, an online comic editing software developed in Japan to support nurturing polyphonic thinking at different educational levels (Suzuki, Mochizuki \& Kubota, 2010; Abe et al.2012). Voicing Board displays a list of preset characters and background images. Before starting each learning unit, the characters and backgrounds depicted in the animated films are included in this list. Characters which are not featured in the animated films (parents, policemen, construction workers, local politicians), are included in the preset list in the event that children want to include them in their stories. Comic strips are prepared in two lessons and saved on the Voicing Board server.

In preparation for the final task in the unit, three comic strips focusing on different problems and solutions are selected and included on butterfly chart worksheets. Students use these worksheets to express their 
opinion either for or against the solutions presented in the comic strips. Then they transfer their opinions onto post-it notes and place them on the butterfly charts drawn on the whiteboard by the teacher. The class then comments on the different opinions and, finally, students vote on the solution they agree with the most. By casting a vote for the different solutions proposed by their peers, children are able to better understand the value of democratic elections and problem-solving processes as dialectical endeavors for which the use of critical thinking skills should play a pivotal role.

\section{Analysis Procedure}

In order to assess learning activities including the critical thinking support materials, rubrics were used that focused on the complexity level and coherence of student ideas as stated in the worksheets. According to the rubric for the worksheets, . shows that the student has mastery of critical thinking skills that exceeds expectations; an . shows that the expected level of mastery is satisfactory; . refers to partial mastery of thinking skills (Kansai University Elementary School, 2012). This type of assessment emphasizes the ideas that children expressed as written text, resorting mainly to explanation and exposure. This study recommends that the proposed learning units proposed integrate critical thinking tools and story-based materials as complementary methods for students to express their ideas. Accordingly, the author proposes an assessment method based on analysis of the ideas expressed by students in the comic strips.

Students use comic strips to depict a problem-resolution process that can be divided into three stages: Cause of the Problem/Problem, Solution of the Situation, and Problem Resolution. Every panel is analyzed in order to determine to which of the three stages it belongs to. It must be noted that the basic comic strip composition suggested in the comic strip planning worksheet follows this structure. Comic strips are also used as an inference process consisting of several related premises that lead to a conclusion (Figure 5). While the premise presents the causes of the problem and possible solutions, the conclusion describes a situation showing that the problem has been resolved. By matching this structure to the actions in the comic strip, the general plot of the story can be visualized to determine if it is organized in a logical manner.

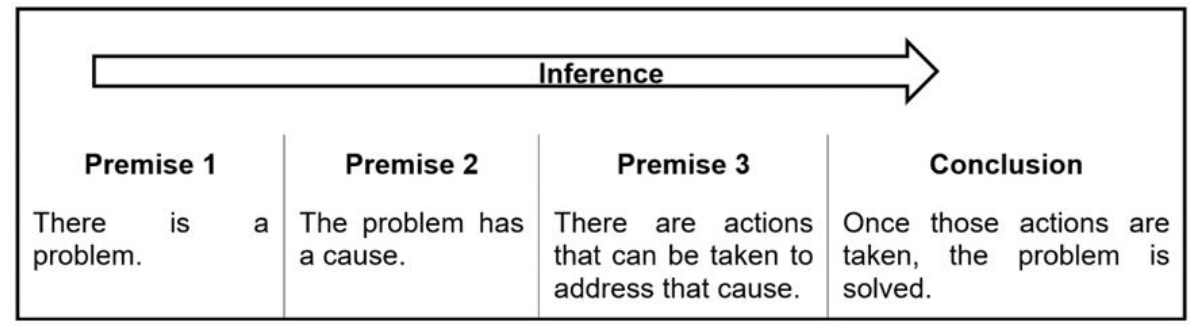

FIGURE 5

Use of Comics Strips As An Inference Process

Source: Elaborated by the author

Based on the table insights, two main conclusions are drawn from evaluating the comic strips. First, the general actions on each panel are analyzed to determine whether the three stages described in the first structure are depicted. Second, the general flow of the story is analyzed to ascertain if the premises and conclusion are logically connected. In other words, the second part of the analysis focuses on whether the student has correctly inferred the causes of the problem based on the solution presented. An assessment of the student's analysis and inference skills, is made, as a result. Analytical skills are implicitly expressed in defining the problem and its causes. Inference skills are explicitly expressed in the proposed solutions to the problem.

This study suggests that students can increase the level of application of their thinking skills (Inferring and Analyzing) through learning activities that use thinking tools and story-based materials and express this in the stories they elaborate about problems in their communities. A rubric is used to analyze the comic strips 
by scoring them on a scale from 1 to 4 , based on the thinking skill application level used for each one (Table 1). The analysis is performed separately by two researchers. In the cases in which the researchers arrive to different results, these differences are addressed, and a final score is settled.

Comic strips that depict the three stages of the problem-resolution process and a logical connection between the solution and the problem are considered as examples of a high thinking skill application. Logically, sound stories representing a solution situation, for example, while omitting either the problem causes/ problem situation or the problem solved situation, are considered as instances of somewhat high thinking skill application. Comic strips that show all three stages, but lack logical coherence are processed as examples of somewhat low application level. Finally, in the comic strips trying to offer a solution to the problem presented in the learning unit but failing to show both the three stages and a logical connection, a low thinking skills application level is suggested. This include stories that do not extend beyond the problem situation and stories that completely omit the solution.

TABLE 1

Thinking Skill Application Levels

\begin{tabular}{ll} 
Level & Indicators \\
\hline High (4 pts) & Shows all three stages of problem causes/ problem situation, \\
& solution situation, and problem solved situation. \\
connection between the causes of the problem and its solution. All three \\
stages dogical connection
\end{tabular}

\section{Results}

A group of students from a 6th grade class participated in learning and assessment activities for both learning units. All of the activities were conducted during the 2019 school year. Each learning unit consisted of six lessons that were taught during a two-week period. When the first unit was taught (early March), the class had 21 students. By the time the second unit was covered (late July - early August) there were 26 students after 5 new students transferred into the. 


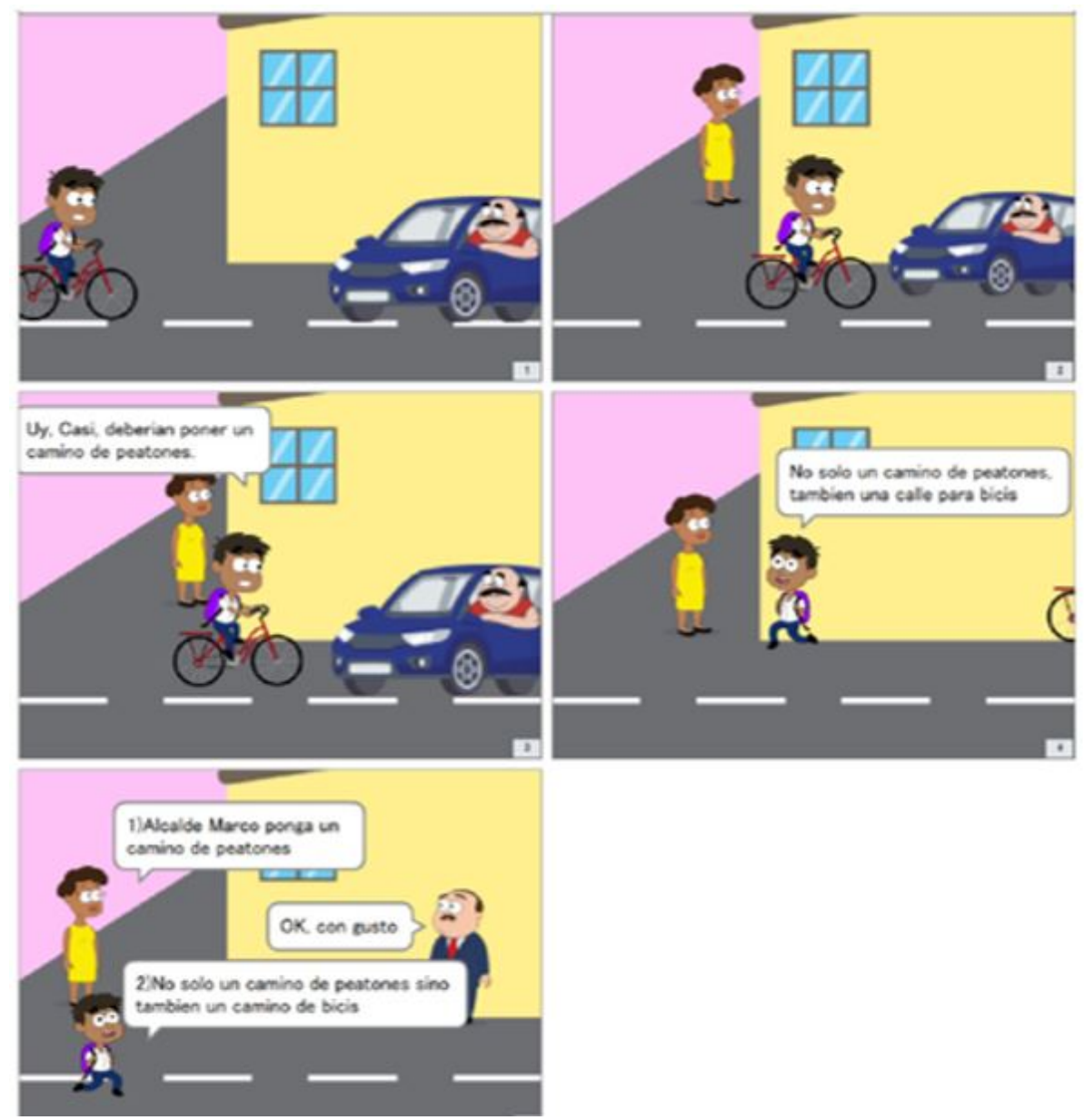

FIGURE 6

Example of Comic Strips Created by Students

Source: Elaborated by the author 


\section{Unit 2 (CR13)}

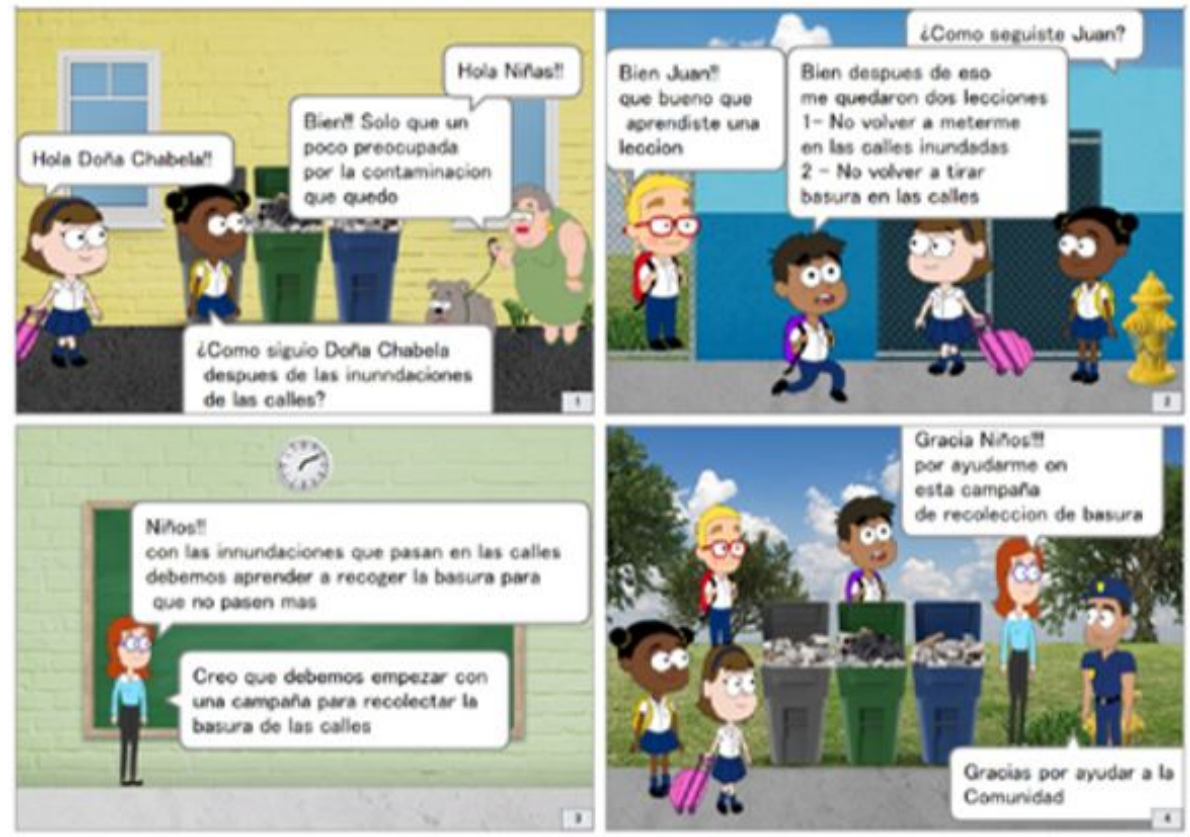

FIGURE 7

Example of Comic Strips Created by Students

Source: Elaborated by the author

The classroom teacher gave the students instructions for both units. During the activity, the teacher received support from the researcher and the computer science teacher. Figure 6 and Figure 7 shows some of the comic strips created by the students for each unit. The comic strip for Unit 1 shows a student who is almost run over by a car while riding his bike on a road without a sidewalk. As a result, the student and his mother filed a complaint and demanded that the mayor build sidewalks and bike paths. This story shows a logical sequence between the cause of the problem and a possible solution. Since it does not depict a situation in which the problem has been solved, it exemplifies applying a higher thinking skill level and scored 3 points.

In the second example, the children reflect on the causes and consequences of littering and then, aided by the teacher, decide to solve the problem themselves. In the last frame, the teacher thanks the students for their help and a police officer congratulates them. These actions suggest that the problem was resolved. Considering that the story displays a logical sequence and includes the three stages that are proposed for a problem-resolution process, it is regarded as an example of a high-level application of thinking skills and received 4 points. Results were then compared after analyzing comic strips used in both learning units to observe if there were any changes in the critical thinking skills level of each student.

A total of 19 students created a comic strip for the first unit and 25 students for the second unit. While 18 students created their own comic strip for both learning units, one student did so for the first unit only, and 7 only for the second unit. The assessment results for both units are shown in Table 2. Among the 18 students that created comic strips for both units, 8 obtained a higher score for the second unit than the first unit. Also, while only 3 students obtained a lower score in the second unit, 7 of the students achieved the same score in both units. These results suggest that the overall performance of the students improved by the second unit. The mean values for the assessment scores for both units reveal a similar trend. A paired Wilcoxon signedrank test was conducted to compare scores obtained by students in each of the two units they participated. It was determined that difference between the scores was statistically significant $(\mathrm{W}=6, \mathrm{p}<0.05)$. Moreover, the mean value $(.=2.78)$ of the second unit scores pertaining to the 18 students that participated in both 
units was higher than the mean value $(.=1.71)$ of the scores attained by the 7 students that joined the group afterwards and participated in the second unit only.

TABLE 2

Learning Unit Results Assessment

\begin{tabular}{|l|l|l|l|}
\hline Participants in Both Units $(n=18)$ & $\begin{array}{l}\text { Thinking Skills Application } \\
\text { Score }\end{array}$ \\
\hline $\begin{array}{l}\text { Ctudent } \\
\text { Code }\end{array}$ & $\begin{array}{l}\text { Chinking Skills Application } \\
\text { SCore }\end{array}$ & CR01 & 1 \\
\hline CR01 & 1 & CR03 & 3 \\
\hline CR03 & 4 & CR04 & 3 \\
\hline CR04 & 3 & CR05 & 1 \\
\hline CR05 & 1 & CR06 & 4 \\
\hline CR06 & 1 & CR08 & 4 \\
\hline CR08 & 1 & CR09 & 4 \\
\hline CR09 & 3 & CR10 & 2 \\
\hline CR10 & 1 & CR11 & 4 \\
\hline CR11 & 4 & CR12 & 1 \\
\hline CR12 & 1 & CR13 & 4 \\
\hline CR13 & 4 & CR14 & 4 \\
\hline CR14 & 1 & CR15 & 3 \\
\hline CR15 & 1 & CR16 & 2 \\
\hline CR16 & 2 & CR17 & 4 \\
\hline CR17 & 2 & CR18 & 2 \\
\hline CR18 & 3 & CR19 & 3 \\
\hline CR19 & 2 & CR20 & 1 \\
\hline CR20 & 1 & & 2.78 \\
\hline$M$ & 2.00 & & 1.22 \\
\hline SD & 1.19 & & 3.00 \\
\hline Man & 1.50 & & \\
\hline & & & \\
\hline
\end{tabular}

Source: Elaborated by the author.

These results shed light on new perspectives as to how story-based teaching materials may enforce critical thinking problem solving skills and assessment of the learning that results. Current studies support the use of story-based media in classroom assessment methods that are based on preexisting critical thinking tests. Gelerstein, Río, Nussbaum, Chiuminatto \& López (2016) resort to the Delphi Report (Facione, 1990) as the basis for designing a test in which 3rd and 4th graders of public and private schools run through a sequence of questions and images embedded in the graphic novel, Around the World in 80 days by Jules Verne. The test focuses on interpretation, analysis, inference, and other skills.

Findings suggest a possible relationship between socioeconomic status and development of critical thinking skills. Similarly, Demirci (2017) uses a pretest and posttest-matched control group design to assess how the use of cartoons to explain scientific concepts impact critical thinking skills among 7 th grade students. The Cornell Critical Thinking Test was used to collect the data and significant differences were found between the scores of the experimental group and the control group.

Other studies present new approaches to assess critical thinking. Kawamoto, Hayashi \& Hirashima (2015) introduce an interactive system in which $4 \mathrm{th}, 5$ th and 6 th grade students are given a four-panel, textless comic strip and five cards with dialogues and explanations. Children were asked to match the panels and cards to create as many stories possible, each of them outlining a different logical pattern.

After a pretest in which the students take notes of the different patterns they find while looking at four panels of comic strips results were compared with the patterns of children in the interactive system. It was concluded that there was a significant increase in the number of stories that the children created. These results uphold the idea that storytelling can support logical thinking. Ariesta \& Purwanti (2019) use observation sheets and questionnaires to ascertain the impact on 4th grader critical thinking skills and 
learning motivation level when comic strips are used to address community problems. Results suggest that there is a link between critical thinking skills and student motivation to learn that also results in increased critical thinking skills.

The aforementioned studies address critical thinking assessment in different ways. Yet, they all share a common attribute where children are given story-based media as a tool for improving critical thinking skills instead of being able to write their own stories. Even for cases in which students answer questions regarding specific events or rearrange a configuration of predefined narrative elements, they are not expected to incorporate their own original ideas into new stories.

By focusing on structures and logical sequences from stories freely created by the students, the assessment method proposed in this article provides novel ways that that students can express their critical thinking abilities when dealing with specific everyday problems. Moreover, comic strips allow children to express their own ideas on how to solve these problems. In this manner, teachers can identify the strengths and weaknesses of the student reasoning process. Specifically, comic strips yield information on how children view the roles of different community stakeholders and how they analyze root causes of problems and on infer possible solutions. Educators can use this information not only to visualize the level of the children's thinking skills at a specific point in time, but also as cues for organizing further instruction aimed at nurturing skills and attitudes that children need to effectively engage in citizenship activities.

\section{Conclusions}

By participating in the proposed learning units, children are able to raise the bar with regards to the thinking skills used in the stories they create. Students who fully participated in the learning process may obtain higher thinking skill application scores than the children who only did it partially. It could be asserted that it is the combined use of story-based media and thinking tools which allows children to express their ideas in more thorough and effective ways.

The two learning units analyzed, provide children the opportunity to understand the different problems that impact community stakeholders and help visualize the root cause of these problems. In this manner, it leads to logical and sound solutions.

It is important to note that given the complexity of social interactions, results are usually influenced by a wide variety of factors.

Animated films created specifically for these learning units present two different problems while sharing a basic structure. They depict little problems related to a broader issue, focusing not only on the actions of the characters, but also on infrastructural issues. Furthermore, both films feature the same two children as the main characters, and similar roles are assigned to them and other characters representing children. Some of them cause or worsen the problem, and others are affected by it or recognize the need of acting towards a solution. However, different stories will inevitably elicit different readings. Likewise, the specific narrative and stylistic characteristics of the films may lead to different thinking processes. These differences may also play a role in the way the students express their ideas in the comic strips they create, and consequently, they may to some extent influence the assessment results.

The suggested increase in the students' ability to present their ideas in logical and coherent ways may also be an effect of positive changes occurring in their storytelling skills. These changes can be viewed in two levels. The first level involves the procedural and technical aspects of the task. When utilizing the comic creation software for the second time, children may be able to engage the task more easily, administering their time more efficiently and expressing a higher degree of complexity in their stories. The second level is related to the children's narrative skills. When creating their second comic, children may face the task with a slightly deeper understanding of how stories work, and as result, they may be able to arrange the dialogs and actions in a more consistent and compelling fashion. 
Although the factors mentioned above must be taken into consideration when assessing the stories created by the students, it can be argued that the learning units and assessment method proposed in this study provide a useful framework for the instruction and evaluation of critical thinking skills for citizen life. Namely, they can support the nurturing of the specific cognitive processes involved in problem-solving and decisionmaking, while taking advantage of the possibilities of storytelling to activate the dispositions children need in order to engage with the social issues of their communities. The learning units are designed to be covered in one school year, but new units can be added in order to establish more comprehensive curricula, spanning across several school years.

It is necessary to keep in mind that the acquisition of the procedural knowledge and attitudes that support the application of critical thinking to situations of everyday life, must be comprehended as a longitudinal process that begins in elementary education and spans into middle and higher education. Such process requires systematic instruction. The learning units developed in this study are proposed as the first step of a process that could begin in the upper grades of elementary education. Later stages of this process should integrate age-appropriate learning activities and educational media, related to the contents of middle school and high school curricula.

Further study on the teaching of critical thinking skills through storytelling and thinking tools should focus on three main tasks. The first task involves the creation of additional story-based media, depicting other problems that currently affect many communities of Costa Rica, such as public insecurity and lack of recreational infrastructure. As a second task, the learning units can be simultaneously implemented in several schools located in different communities. By allowing comparisons based on geographic and socioeconomic factors, the results of these activities may yield new insights on the effects of narrative learning regarding the application of critical thinking skills. A final task may include the creation of learning units targeted to other countries, following the basic structure and procedures of the units already implemented in Costa Rica, in order to observe how children immersed in different cultural environments use storytelling to approach similar problems in their communities.

\section{REFERENCES}

Abe, Y., Kusumoto, M., Kubota, Y., Funaoi, H., Suzuki, H., \& Kato, H. (2012). Understanding the Feelings and Scenes of "Gokintsune" through Comic Creation. Japan Journal of Educational Technology, 36(Suppl.), 141-144. [阿 部裕子, 楠本誠, 久保田善彦, 舟生日出男, 鈴木栄幸, 加藤浩 (2012). マンガ作成による「ごんぎ つね」の心情と情景の理解. 『日本教育工学会論文誌』36(Suppl.), 141-144.]

Arce, H. (2019). Competencias ciudadanas: una reconstrucción conceptual en el marco de la Educación Cívica costarricense. Revista Actualidades Investigativas en Educación, 19(2), 1-20. doi: https://doi.org/10.15517/aie. v19i2.36904

Arce, H., \& Chévez, F. (2016). Perspectivas pedagógica, epistemológica y metodológica del programa de estudios de la asignatura de educación cívica en Costa Rica. Revista Electrónica Educare, 20(1), 492-506. doi:10.15359/ ree.20-1.24

Ariesta, F., \& Purwanti, E. (2019). Build Critical Thinking Skills of Elementary School Students through Comic Strips Social Science-Based Problem. The 1st Workshop on Multimedia Education, Learning, Assessment and its Implementation in Game and Gamification in conjunction with COMDEV 2018, Medan Indonesia. doi: htt ps://doi.org/10.4108/eai.26-1-2019.2282933

Bujanda, M.E. \& Campos, E. (2014). The Adaptation and Contextualization of ATC21S by Costa Rica. In P. Griffin, B. McGaw, and E. Care, (Eds.) Assessment and Teaching of $21^{\text {st }}$ Century Skills (pp. 245-256). New York: Springer.

Chance, P. (1986). Thinking in the Classroom. A Survey of Programs. New York: Teachers College, Columbia University. 
Comer, K. (2015). Illustrating Praxis: Comic Composition, Narrative Rhetoric, and Critical Multiliteracies. Composition Studies, 43(1), 75-81.

Demirci, F. (2017). The Effects of Using Concept Cartoons in Astronomy Subjects on Critical Thinking Skills among Seventh Grade Students. International Electronic Journal of Elementary Education, 10(2), 243-254. doi: https:/ /doi.org/10.4108/eai.26-1-2019.228293310.26822/iejee.2017236119

Ennis, R.H. (1985). A Logical Basis for Measuring Critical Thinking Skills. Educational Leadership. 43, 44-48.

Facione, P. A. (1990). Critical Thinking: A Statement of Expert Consensus for Purposes of Educational Assessment and Instruction. Study Findings and Recommendations. Retrieved from http://assessment.aas.duke.edu/documents /DelphiReport.pdf

Flynn, N. (2018). Comic Strips in the Literature Classroom: How Multimodal Learning Can Create Better Citizens. CEA Forum, 47(1), 2-27.

Frey, N. \& Fisher, D. (eds.) (2008). Teaching Visual Literacy: Using comic books, graphic novels, anime, cartoons, and more to develop comprehension and thinking skills. Thousand Oaks, California Corwin Press

Gelerstein, D., Río, R., Nussbaum, M., Chiuminatto, P., \& López, X. (2016). Designing and Implementing a Test for Measuring Critical Thinking in Primary School.Thinking Skills and Creativity, 20, 40-49. doi: https://doi.org/ 10.1016/j.tsc.2016.02.002

Griffin, P., McGaw, B. \& Care, E. (2012) Assessment and Teaching of 21st Century. Skills. Estados Unidos : Springer.

Halpern, D. (1998). Teaching critical thinking for transfer across domains - Dispositions, skills, structure training, and metacognitive monitoring. American Psychologist, 53(4), 449-455.

Kansai University Elementary School Division (2012). Kansai University Elementary School Division Thinking Skill Instruction Method. Tokyo: Sakurasha. [関大初等部 (2012). 『関大初等部 思考力育成法』さくら 社. ]

Karaki, K. (2008). Social participation and social studies education for children -The structure of Japan-style service. Tokyo: Toyokan. [唐木清志. (2008). こどもの社会参加と社会科教育一日本型サービ ス\#ラーニン グの構想』東洋館出版社. ]

Kasuga Gakuen Compulsory Education School (2017). "Teaching Thinking Skills"-for fostering logical thinkingCollection of practice examples and assessment Vol. 5. Tsukuba: Kasuga Gakuen Compulsury Education School. [つくば市立春日学園義務教育学校（2017）『「思考スキルの授業」〜論理的思考力を 育むために〜実践事例集十評価Vol.5』つくば市立春日学園義務教育学校. ]

Kasuga Gakuen Compulsory Education School (2015). "Time for thinking" Collection of practice examples Vol. 3. Tsukuba: Kasuga Gakuen Compulsory Education School. [つくば市立春日学園義務教育学校（2015）

『「考える時間」実践事例集 Vol. 3』つくば市立春日学園義務教育学校. ]

Kawamoto, K., Hayashi, Y., \& Hirashima, T. (2015). Open-ended and Interactive Learning Using Logic Building System with Four-Frame Comic strips. Study Report of the Japanese Society for Information and Systems in Education. 29(6), 55-60. [川本佳代, 林雄介, 平嶋宗 (2015). 四コマ漫画を題材としたオープンエンドかつインタラクテイブな論理組み立て演習の 実現.『教育システム情報学会研究報告』29(6), 55-60. ]

Kurokami, H., Kojima, A., Taizan, Y. (2012). Thinking Tools - I want to teach how to think. Osaka: Kansai University. [黒上晴夫，小島亜華里，泰山裕（2012）。『シンキングッール〜考えることを教え たい〜」』. 関西大学. ]

Kusumi, T. (2013). Critical Thinking for Good Citizenship. Psycology. (61), 5-8. [楠見孝 (2013) 良き市民のため の批判的思考. 『心理学ワールド』(61), 5-8.]

Kusumi, T. \& Michita, Y. (2016). Critical Thinking and Civic Literacy: $21^{\text {st }}$ century skills for changing education, media and society. Tokyo: Seishinshobo. [楠見孝, 道田泰 (2016) 批判的思考と市民リテラシー：教育、メ デイア、社会を变える21世紀型スキル』誠信書房. ]

Ministerio de Educación Pública de Costa Rica [MEP] (2006). Actividades de pensamiento crítico y creativo. Retrieved from https://bit.ly/33PtQfC 
Ministerio de Educación Pública de Costa Rica [MEP] (2013). Proyecto ética, estética y ciudadanía: Programas de estudio de estudios sociales y educación cívica, primero y segundo ciclos de la educación general básica. Retrieved from https://bit.ly/2PfMDLQ

Ministerio de Educación Pública de Costa Rica [MEP] (2009). Proyecto ética, estética y ciudadanía: Programas de estudio de estudios sociales y educación cívica, tercer ciclo de la educación general básica y educación diversificada. Retrieved from https://bit.ly/2E1oC69

Ministerio de Educación Pública de Costa Rica [MEP] (2019). Nómina de centros educativos 2019. Retrieved from https://bit.ly/2YkZDUn

Ministry of Education, Culture, Sports, Science and Technology (Japan) (2011). Development of period for integrated study to foster the abilities currently required-Elementary school edition. [文部科学省（2011）。『今、求め られる力を高める総合的な学習の時間の展開 小学校編』．]

Murata, Y., \& Yamaguchi, M. (eds) (2010).Education in Contemporary Japan-System and Content-. Tokyo: Toshindo.

Paul, R.W., Binker, A.J.A. \& Weil, D. (1990). Critical Thinking Handbook: K-3. Foundation for Critical Thinking, Sonoma State University.

Sans, A., Jenkins, M., \& Elizondo, G. (2009). Programa de Ética, Estética y Ciudadanía. Informe de Evaluación Fase I. Costa Rica: PNUD. Retrieved from https://erc.undp.org/evaluation/documents/download/3629

Schlegel, M.J. (1995). A Handbook of Instructional and Training Program Design. New York: ERIC Document Reproduction Service.

Suzuki, K. (2005). Instructional Design for E-Learning Practices. Japan Journal of Educational Technology. 29(3), 197-205. [鈴木克明（2005)。e -Learning 実践のためのインストラクショナルデザイン。『日本 教育工学会論文誌』29(3) , 197-205. ]

Suzuki, H., Mochizuki, T., \& Kubota, Y. (2010). Applying Manga-Based Thinking Method to Help Teacher Training Program Students to Make Lesson Plans. Japan Society for Science Education. 34(2), 177-188. [鈴木 栄幸, 望月俊男, 久保田善彦 (2010). マンガ表現法による振り返りが教育実習生の指導案改善に 与える効果. 『日本教育工学会研究報告集』34(2), 177-188. ]

Taizan, Y. Kojima, A. \& Kurokami, H. (2012). Study on the Subject-Common Thinking Skills Observed in Elementary School Curricula. Japan Society for Educational Technology $28^{\text {th }}$ National Congress. 489-490. [泰 山裕, 小島亜華里, 黒上晴夫 (2012). 小学校学習要領にみる教科共通の思考スキルに関する研 究。『日本教育工学会 第28回全国大会』，489-490. ]

Taizan, Y. Kojima, A. \& Kurokami, H. (2014). Study of Subject-Common Thinking Skill for Systematic Information Education: From Analysis of the Government Curriculum Guidelines and Commentary to it. Japan journal of educational technology. 37(4),375-386. [泰山裕, 小島亜華里, 黒上晴夫 (2014). 『体系的な情報教育に 向けた教科共通の思考スキルの検討 学習指導要領とその解説の分析から』. 日本教育工学会 論文誌, 37(4), 375-386. ]

Tamura, M. \& Kurokami, H. (2017). Thinking Tools Used in “Deep Learning”. Shogakukan. [田村学，黒上晴夫 （2017）.『「深い学び」で生かす思考ッール』小学館.］

Yamashita, S., Yuizono, K., Umezawa, S., \& Kasuya, M. (2017). Raising children for continuous inquiring aimed to build a "better society" - Instruction for promoting "decision" learning as the essence of Social Studies. University of Tsukuba Elementary School Study Bulletin, 73, 27-36. [山下真一, 由井園健, 梅澤真 一，粕谷昌良（2017）「ょりょい社会」の形成に向け、問い続ける子どもを育む一社会科の 本質に迫る「きめる」学びを生み出す授業一『筑波大学付属小学校研究紀要』73, 27-36. ]

\section{BY-NC-ND}

